\title{
Cancer Cell Growth
}

National Cancer Institute

\section{Source}

National Cancer Institute. Cancer Cell Growth. NCI Thesaurus. Code C19387.

The unregulated growth of cancer cells insofar as growth control and contact inhibition. 